Article

\title{
Constructed Governance as Solution to Conflicts in E-Waste Recycling Networks
}

\author{
Fernanda Pedro ${ }^{1}\left(\mathbb{D}\right.$, Ernesto Giglio ${ }^{1, *(\mathbb{C})}$, Luis Velazquez ${ }^{2}$ and Nora Munguia ${ }^{2}(\mathbb{D}$ \\ 1 Department of Administration, Paulista University-UNIP, São Paulo 05353-050, Brazil; \\ FERNANDACONTATO9@gmail.com \\ 2 Department of Industrial Engineering, University of Sonora, Sonora 83260, Mexico; \\ luis.velazquez@unison.mx (L.V.C.); nora.munguia@unison.mx (N.M.) \\ * Correspondence: ernesto.giglio@gmail.com
}

Citation: Pedro, F.; Giglio, E.; Velazquez, L.; Munguia, N. Constructed Governance as Solution to Conflicts in E-Waste Recycling Networks. Sustainability 2021, 13 1701. https://doi.org/10.3390/ su13041701

Academic Editor: Barry D. Solomon Received: 21 December 2020

Accepted: 29 January 2021

Published: 4 February 2021

Publisher's Note: MDPI stays neutral with regard to jurisdictional claims in published maps and institutional affiliations.

Copyright: (c) 2021 by the authors. Licensee MDPI, Basel, Switzerland. This article is an open access article distributed under the terms and conditions of the Creative Commons Attribution (CC BY) license (https:// creativecommons.org/licenses/by/ $4.0 /)$.

\begin{abstract}
Electronic waste (e-waste) has become an increasingly pressing problem worldwide because of the increase in the volume of waste, without a corresponding increase in the recycling rate. E-waste recycling models show a low percentage of reuse, at around $17.4 \%$ in the world, $11 \%$ in Latin America, and 3\% in São Paulo City, Brazil. The sources of conflicts relating to e-waste recycling networks are diverse, including asymmetries of objectives, knowledge, ethical values, and culture of sustainability, which indicates the need for a system of regulatory mechanisms. The article's main proposition is that constructed governance, which is a collective process involving many actors, could be an alternative to e-waste recycling management. The city of São Paulo was chosen to be analyzed. Using an abductive methodology, the data analysis shows a fragmented network, with conflicts of interest among commercial and sustainability objectives, an absence of legal knowledge, and increases in the incorrect disposal of waste. However, initiatives in small groups in Brazil, which can be considered as examples of constructed governance, show a better volume of waste and the transportation of waste material to the right destination. The authors argue that constructed governance could be an efficient tool for e-waste recycling management systems. Besides, the article offers a matrix of indicators that can be used by both researchers and recycling managers.
\end{abstract}

Keywords: e-waste; recycling; sustainability; constructed governance; networks; asymmetry

\section{Introduction}

Electronic waste (e-waste) is a growing global problem because of the increase in the volume of waste without a corresponding increase in the recycling rate. The rate of the formal recycling of electronics globally is $17.4 \%$ and only $0.7 \%$ in South America [1]. The industry continually calls for product renewal because of rapid technological development with ever shorter life cycles, thus worsening the problem [1].

This increase is observed in the United Nations monitoring report on e-waste [1]. In 2019, the world produced $53.6 \mathrm{mt}$ or approximately $7.3 \mathrm{~kg}$ of e-waste per capita [1]. Asia produced $24.9 \mathrm{mt}$, Americas $13.1 \mathrm{mt}$, Europe $12 \mathrm{mt}$, Africa $2.9 \mathrm{mt}$, and Oceania $0.7 \mathrm{mt}$. The forecast for 2030 is $74.7 \mathrm{mt}$ or an average of $9 \mathrm{~kg}$ per capita. In 2014, the value per capita was $6.4 \mathrm{~kg}$. The rapid technological advance can explain the increase in electronics production, the appeal to consumption for new products, the programmed obsolescence [2], or the few expensive repair options.

On the other hand, the capacity of recycling is not keeping up with the growing total e-waste generated. Table 1 presents the 2020 data related to the percentage of recycled electronic material by continent and its average consumption per capita. 
Table 1. Percentage of e-waste recycled and consumption by continent.

\begin{tabular}{ccc}
\hline Region & \% E-Waste Recycled & Kg Per Capita \\
\hline Europe & 42.5 & 16.2 \\
\hline Asia & 11.7 & 11.7 \\
\hline America & 9.4 & 13.3 \\
\hline Oceania & 8.8 & 16.1 \\
\hline Africa & 0.9 & 2.5 \\
\hline Source: Forti et al. [1] (p. 14). & &
\end{tabular}

North America recycles 15\%, Central America 3\%, and South America 0.7\%, the lowest index among all major regions [1]. Brazil is the second-largest generator of electronic waste in the Americas, behind the United States [3], with $2.14 \mathrm{mt}$ [1]. Globally, in 2019, electronic products in the computer category totaled about of 420 million digital devices, one cell phone per inhabitant, 230 million smartphones in use, and 180 million computers [1].

The problem may be more significant because it is challenging to obtain reliable global data on the real situation of electronic waste recycling, partly because of the informal chain, the irregular disposal in landfills and dumps, or the lack of public interest in collecting statistics on the theme. For example, it is estimated that Brazil generates around 2.14 million tons of waste annually, compared to 465 thousand tons in Argentina and 318 thousand tons in Colombia. Still, there is no clear information on the volume represented by e-waste and its destination [4].

Unsustainable, even illegal, waste electrical and electronic equipment (WEEE) recycling practices are presented both in Europe and the rest of the world; however, Latin America and the Caribbean countries get the worst indicators due to insufficient or inadequate legislation [5]. Older estimates indicate that in 2007 around 6000 and 9000 tons of electronic waste were discarded in Colombia, and around 7000 tons in Chile, while Argentina generated over 20,000 tons [6]. A key reason for the poor e-waste data is the lack of clear legislation [2] and the lack of precise mechanisms for assessing the total e-waste generation [7]. Some experts affirm that the WEEE management in Latin America may be improved by fostering partnerships with local industries, universities, and governmental agencies to increase technical assistance, advising services, and capacity building [8-10]. Within this framework, it is possible to enhance a circular economy on electronic products by recycling, recovering, and reusing them as secondary raw materials [11].

The public policy models applied to e-waste recycling are not working, even considering countries and regions with high recycling rates, as in East Asia (Japan, China, and Korea) with 20\%, or Northern Europe (United Kingdom, Sweden, and Norway) with $59 \%$ [1].

This context raises questions about which factors of success are preponderant: if there is a predominant factor, or the success depends on conjugated variables; if it is a cultural, educational, or consciousness-related issue; if industrial production needs to be controlled; or if central governance must be established. These questions have been pointed out in the literature [12,13], but there is no agreement about a better model.

Research comparing the situations in Switzerland and India [14] shows that it is possible to obtain results by inputting industry and importer manufacturer responsibility into the circular economy sustainability program. India is trying to imitate the Switzerland model, but it is difficult to control its industry because of its informal chain. Ryen, Gastaud and Babitt [15] affirm a mismatch between the rapidly changing market and the slowly evolving public policies and strategies. The authors propose natural ecosystems applied to a circular process, driving public policies, but no empirical research has been conducted in this direction.

An article on the global e-waste chain [16] shows that countries like China, India, and Pakistan are the ones that receive the most e-waste from developed countries. 
In Latin America, difficulties have been reported in the execution of solid waste plans. First, only $30 \%$ of Latin American countries have legislation on solid waste, including electronic waste [17]. The second problem is that there are no formal and valid records on the generated waste, the collected and recycled waste $[18,19]$.

The third problem is the absence of an integrated reverse logistics system, with the collection, distribution, disassembly, and replacement of products on the market [17]. Countries seeking the most effective solution are Colombia, Brazil, and Peru [1]. A fourth problem is the behavior of the residential consumer, who seeks ease of disposal, and the industrial consumer, who seeks profit. These actions feed the informal e-waste chain, offering withdrawal facilities and a competitive price.

According to data [1,17], 50\% of household collection in Latin American is informal, $15 \%$ is public, $2 \%$ is formal, and $33 \%$ is reused. For industrial consumers, $19 \%$ is informal, $14 \%$ is public, $5 \%$ is formal, and $38 \%$ is reused.

Estimates indicate that annual losses from legal and formal nonuse of e-waste in Brazil are in the order of USD 13 billion annually [17]. In addition to this financial aspect, waste without proper destination causes damage to public health [16] due to soil contamination and water contamination in rivers and reservoirs. The government's cost to attack the problem is about USD 102.5 per ton to all waste [17], but, until now, the Brazilian government has not had a specific plan for e-waste recycling program.

Other researches value the social implication of recycling in general [20,21], proposing programs to develop cooperatives and local associations. These Brazilian articles discuss the problem of pickers and homelessness in towns and how legal documents, like the Solid Waste Program 2010 to call organizations to include these people. Studies, however, have shown that the informal market is the usual way to initiate this inclusion process. The propositions and the reality allow for a systemic vision of the e-waste task. Academic and management researchers have created models based on circular economy [22], or focused on consumers [23], supply chain improvement [24], or technology [25]. All the propositions are closed to the idea of reverse logistics, which, in e-waste field, pass by pickers, informal collectors, local arrangements, trying to join the legal, the ethical, the social, the economic and the sustainable objectives.

The challenge became more complicated because electronic waste is a big business, attracting all kinds of enterprise and business models, which are not always concerned with sustainability issues. It is estimated that USD 10 billion dollars were collected only by recycling the $17.4 \%$ of e-waste legally collected in the world in 2019 [1]. It should be noted that the remaining $82.6 \%$ of electronic waste generated had an uncertain destination, part of which is due to the informal chain existence in this environment [1]. The numbers show that the power of a profit orientation in the e-waste recycling cause low environmental gains and could be dangerous for people since electronic products contain numerous heavy metals [2].

There is a group of authors maintaining that network governance is a thoughtful way to solve the problem, and their works present a variety of models and arguments: about the legitimacy of governance [26], or social participation and relational governance [27,28], or systemic view to building governance [29]. The central question seems to be who participated, how, and who decided.

An approach that has shown positive results from empirical data is based on collaborative governance [30-32]. The concept assumes that actors of all segments, like government, civil society, industry, and the third sector need to join to do the task. However, literature on collaborative governance [33-37] is not clear about the process of this collective action, i.e., how to begin, to develop, and to decide on the mechanisms, and implement them. This study seeks to fill this gap in the literature.

The next section presents the theoretical assumptions and their connection with the research problem. 


\section{Theoretical Assumptions and the Research Problem}

Section 1 offers a picture of e-waste recycling characteristics, asymmetry issues, and a variety of approaches to managing and solving the problem. According to the authors, the ewaste recycling inefficiency can be explained by the many conflicts among the organizations associated with e-waste recycling. The most discussed conflicts are based on the objectives of sustainability, the quality of processes in the treatment of the material, or knowledge of the reverse chain [38-41].

According to Weerasundara et al. [42], the problem lies in constructing specific public policies on e-waste. Electronic waste is usually placed within the general solid waste plan, which involves various products. However, e-waste has physical and chemical composition characteristics that require a specific plan for collection, storage, separation, and forwarding in a circular chain.

From the sociotechnical perspective, the authors claim that the informal chain is a problem because it works with market practices, with little concern for the quality of sustainable processes. Considering Latin America, there are informal chains for the collection, separation, and sale of materials that do not follow the legislation [43].

Similarly, the e-waste recycling situation has been explained in terms of the conflict between commercial and sustainable interests. Even among those who follow the legislation, entrepreneurs who originate or obtain e-waste can be seduced by price offers, leaving aside some care for the environment, such as requiring adequate treatment of the material by the acquiring company. Small companies make agreements with a local partnership, driven by friendship more than by technical requirements [39]. This point is important because governance depends on relationships, but not on favoring friends [41], and social capital influences governance practices [44]. These points are related to e-waste management, which is a problem in Latin America $[9,45]$.

According to these authors, the system does not work because there is no integrated view. This means that there is no process that begins in the product industry and involves the collection, separation, reuse, and appropriate disposal of unused material. In other words, the e-waste recycling task seems to demand a network perspective. This problem appears to be associated with a lack of commitment from actors [2].

Table 2 shows the characteristics of e-waste recycling that indicate the network format. The categories were selected from Giglio, Ryngelblum, and Jabbour [46], and the information was collected from secondary sources, especially cited reports and technical interviews with consultants of nongovernmental organizations (NGOs), like Abrelpe, United Nations University, and Think Circle.

Table 2. The characteristics of e-waste recycling that indicate the network format.

\begin{tabular}{|c|c|}
\hline \multicolumn{2}{|r|}{ Network Format Signals } \\
\hline Variable & Characteristic of e-waste recycling \\
\hline Task Complexity & $\begin{array}{l}\text { Collect and separate electronic components require technical training, } \\
\text { knowledge about environmental legislation, government incentives, and } \\
\text { sustainable management modes. }\end{array}$ \\
\hline Interdependence & $\begin{array}{l}\text { The recyclable chain is circular. Each actor depends on the other, from the } \\
\text { beginning, when the e-waste is generated and must be correctly disposed to } \\
\text { obtain sustainable and economic results; until the end, in the destination of } \\
\text { reusable and non-reusable material. }\end{array}$ \\
\hline Necessary Exchanges & $\begin{array}{l}\text { Suppliers and buyers need to exchange information about collective services } \\
\text { (such as collection logistics), about usable technologies (such as trackers), } \\
\text { about changes in practices and laws of the sector. }\end{array}$ \\
\hline Presence of problems and group objectives & $\begin{array}{l}\text { The expected collective goal is the correct destination for e-waste. The common } \\
\text { problem/challenge is to follow the rules in the chain since the network is } \\
\text { extensive and without the possibility of control. Then, secondary problems } \\
\text { arise, such as opportunistic behavior and price negotiations. }\end{array}$ \\
\hline
\end{tabular}


Table 2. Cont.

\begin{tabular}{cc}
\hline $\begin{array}{c}\text { Network Format Signals } \\
\text { solve possible conflicts }\end{array}$ & $\begin{array}{c}\text { There are asymmetries of interests and ethical values, with actors who act } \\
\text { through a profit logic. Legal and enforcement issues may not be met. There } \\
\text { may be more powerful actors, such as large supplier organizations, or buyers, } \\
\text { who seek to impose market logic. There are asymmetries of technical } \\
\text { capacities, causing points of resistance and inefficiency in the chain. These } \\
\text { common problems require governance. }\end{array}$ \\
Governance Presence & $\begin{array}{c}\text { There is formal governance, mainly through solid waste plans, existing in } \\
\text { practically all countries, from which the network is formally organized. There } \\
\text { is also an informal market practice, with the complexity of monitoring the task. }\end{array}$ \\
\hline
\end{tabular}

Sourcing: Authors, adapted from Giglio, Ryngelblum, Jabbour [46].

Authors who have investigated e-waste recycling networks in urban cities confirm the existence of the problems pointed out in the previous paragraphs, such as the lack of a specific public policy, the dominance of informal chains, the opposition between the market logic and sustainability logic, and the absence of control mechanisms and collective action standards [47,48].

Our interpretation is that the problems above refer to a lack of collectively constructed governance, that is, mechanisms associated with how to deal with e-waste that have been produced collectively by the actors. It seems clear that formal governance and legal governance are not enough to attain desirable results.

The idea of constructed governance, as a social process in public service networks, is accepted among public agents. Since e-waste recycling is complex, with several agents, there are conflicts of a diverse nature, including disputes relating to the objectives, knowledge, ethical values, and culture of sustainability, thus indicating the need for a decision process that involves all the actors. The actors need to make decisions collectively concerning actions, functions, powers, and hierarchies [49].

This process is the focus of the present research: to describe the problems and conflicts inside the e-waste recycling network and use constructed governance as a thoughtful way to solve them. The central assumption is that if individuals join to adjust collective action mechanisms, the collective objective assumes the first place in their priorities. This principle is present in the area of Group Dynamics [50-52].

The problems are more evident in urban cities, and authors refer to a certain repetition of the operating structure around the world, especially in Latin America [2]. For this reason, the city of São Paulo was selected as an exemplary case, because it is the largest producer of e-waste in Latin America and previous data on secondary sources, which indicate the presence of the problems pointed out in the earlier paragraphs.

The initial data, collected in reports from government agents and presidents of recyclable material cooperatives, indicate that a business logic prevails in the city of São Paulo, with competition strategies inside a fragmented informal chain. A chain that follows sustainability principles also exists, but with a reduced capacity for recycling materials of around 3\%, compared to the informal chain.

With these business logic and chain characteristics, constructed governance becomes difficult or even impossible. The factors listed in the academic literature that favors the emergence of collaborative governance can be summarized as follows:

(a) a relationship environment based on trust and commitment [53,54];

(b) the acceptance of collective objective as more important than individual objectives (for example, correct and sustainable destination of electronic waste, even in the face of opportunities to earn more by following another path) [55];

(c) awareness and acceptance to work together [56];

(d) collective efforts to continually adjust governance, according to changes in the environment (such as laws or technologies) and the network (such as the inclusion and exclusion of organizations) $[57,58]$. 
The guiding proposition is that the constructed governance made by the actors themselves, which are directly involved with the task, is a solution path for improving e-waste recycling efficiency. São Paulo already has a detailed solid waste plan, created by the government, but there seems to be a gap between the plan and the daily practice of dealing with e-waste.

The proposition assumes the following statements, which together form the theoretical foundation of this study.

(a) The e-waste recycling cases show that it is a complex task, because specific knowledge is involved, creating interdependence between actors, which is characteristic of a network phenomenon.

(b) Because of the intense asymmetry among actors, the social network approach can highlight the behavior of the actors and the collective actions. The aim of this approach is to make the actions, decisions, and modes associated with carrying out the task depend on the relationship matrix. Trust, commitment, cooperation, and power are central to the matrix approach.

(c) The examples of constructed governance show that this equation, associating relationship and operations, seems to work better in small groups.

(d) While the authors value the capacity to join actors, as the aim of collaborative governance, we assume a lack of knowledge in the dynamic group process that allows the group to create mechanisms of governance and make decisions.

After discussing the starting points, the next step is to analyze the e-waste recycling data in São Paulo, support (or not support) the basic assertions, and point out the model's components that emerge from the data. This methodology path, known as an abductive methodology, consists of merging the initial data with a proposal, conducting research, aggregating elements in the proposal, and reaching the end with a more robust model based on empirical evidence [59,60].

\section{Materials and Methods}

The first step was to organize the data on the characteristics of e-waste recycling in the world. We used the following schedule: (a) understand the e-waste recycling network characteristics; (b) recognize these characteristics in Brazil; and (c) focus the analyses on São Paulo City. The methodology is exploratory and descriptive, collecting data from primary and secondary sources.

\subsection{E-Waste Recycling Networks Characteristics}

The task of e-waste recycling brings together various actors in society, including employees in the electronics industry, residential consumers, companies that generate waste, waste collectors, recycling cooperatives, component separation organizations, buyers of already dismantled materials, international aid agencies, such as the UN, following global programs of the 2030 Agenda, and agents of the third and fourth sectors, such as NGOs, unions, and other associations.

This myriad of organizations forms a worldwide chain of sustainability and reverse economy, which unfolds in sub chains in countries and regions, until it reaches city and neighborhood networks. Considering the 2030 Agenda [61], which is the broadest global sustainability plan in force today, we think that the means of implementation from the sustainable development goals (SDGs) of health and well-being (SDG 3), industry, innovation, and infrastructure (SDG 9), sustainable cities and communities (SDG 11), responsible consumption and production (SDG 12), land life (SDG 15), and partnerships (SDG 17) are the most important to consider when analyzing e-waste recycling.

In various countries, specific reliable waste solution programs have been created, including electronic ones. Actors have tried to implement these programs in each region, and this is where problems arise, because local actors may not follow the program guidelines. For example, large companies may prefer to negotiate their material sales, or consumers may not have a separate material collection grid (resulting in indiscriminate disposal and 
collection), or third-party collection companies may not act by separating e-waste, solid waste, and regular waste. In short, it is in the actions of these actors that success or failure occurs.

Articles comparing regions and cities [14] found a similar structure and functioning. The commitment of the actors is one of the keys to success, especially the leading actors directly involved in the collection and treatment of the materials. According to the theoretical focus of constructed governance, commitment is a necessary condition for actors to talk about and decide how to carry out collective work.

The absence of commitment was verified in e-waste management examples that use hierarchical models, either through government intervention, with solid waste programs that detail the actions to be performed, or through the influence of dominant actors, who dictate rules and operations. In these cases, there are problems associated with resistance, opposition, or a lack of commitment by the actors [39], which hinder the task efficiency.

Hierarchical models can be a problem at the limits of the network, where public programs are implemented, because networks cannot be entirely managed and governed with hierarchies. The networks' actors determine the direction of collective action and the achievement of the objective, so this decision process should be the focus of solid waste management.

In this article, it is argued that micronetworks (in a neighborhood, for example) can be organized in such a way that the actions of the network are oriented towards sustainability. These micronetworks can be used as examples to influence other micronetworks, thus spreading to the broader network of which they are a part. This is the case in some places in São Paulo city, as we will discuss later.

Once the data have been analyzed and organized, the contextual framework, with the factors that determine the low efficiency and results of e-waste recycling, can be produced. This framework includes the problems generated by hierarchical models; the presence of conflicts of interest, especially regarding profit objectives, which are opposed to sustainability objectives; the lack of commitment from suppliers (consumers and companies); and failures in the collection and distribution logistics.

In sum, there are some recurrent characteristics of the electronic waste recycling networks in the world that are related to formal regulations, detailed rules, and the market reality, with its fragmented nature. This result reinforces our statement about the necessity to think about and test models based on other principles, e.g., constructed governance.

Regarding our case study, São Paulo City, the next section presents the regulation rules for e-waste in Brazil, showing that they are very detailed but have problems associated with their implementation.

\subsection{Laws, Regulation, and Mechanisms of e-Waste Recycling in Brazil}

In Brazil, federal law No. 12,305 of 2010 instituted the national policy for solid waste, where individuals, legal entities with public and private rights, are subject to this law if they are generators of this waste. There is a shared responsibility concerning a product's lifecycle, from the extraction of its raw material to the final disposal of the waste that is impossible to treat. Article 33 of the law describes the obligations of manufacturers, importers, distributors, and traders to implement reverse logistics systems in conjunction with public collection capacities. In the list of types of mandatory waste in the reverse logistics system is item 6, which relates to electronic products.

The program is integrated with the national environment policy, the national education policy, and the basic sanitation policy. In the management of solid waste, an order of priority is established, namely: no generation, reduction, reuse, recycling, treatment of solid waste, and environmentally appropriate final disposal of waste.

However, the country's complexity and regional differences pose difficulties that hinder inspection. It seems that reverse logistics in Brazil is growing in relation to products like car batteries and tires [62]. With respect to e-waste, there is a long way to go. 
Electronic waste can originate from the industrial chain or domestic waste. Table 3 shows the distribution of the volume and value of e-waste, compared to other waste types. Electronics are responsible for $53 \%$ of the amount billed for the category, "other materials." This means that any policy or program needs to consider the business's power in the network. This consideration does not appear under Brazilian law.

Table 3. Status of e-waste and other materials in Brazil, at 2017 and 2018.

\begin{tabular}{|c|c|c|c|c|c|c|}
\hline \multirow[t]{2}{*}{ Waste } & \multicolumn{2}{|c|}{$\begin{array}{l}\text { Collected Amount } \\
\text { (BRL/Thousand) }\end{array}$} & \multicolumn{2}{|c|}{$\begin{array}{l}\text { Collected Volume } \\
\text { (Tons) }\end{array}$} & \multicolumn{2}{|c|}{$\begin{array}{l}\text { Average Price Collected Material } \\
\text { (BRL/Kg) }\end{array}$} \\
\hline & 2017 & 2018 & 2017 & 2018 & 2017 & 2018 \\
\hline Electronics & 81 & 178 & 68 & 145 & 1.19 & 1.23 \\
\hline Oil and Fats (Liters) & 108 & 89 & 169 & 146 & 0.64 & 0.61 \\
\hline Other Materials not specified & 21 & 50 & 167 & 149 & 0.12 & 0.33 \\
\hline Composition & 32 & 22 & 183 & 89 & 0.18 & 0.25 \\
\hline Total Other Materials & 242 & 339 & 587 & 528 & 0.41 & 0.64 \\
\hline
\end{tabular}

In 2019, the reverse logistics sector agreement for household electronics and its components was created to establish the terms of operation, implementation, and structure of this policy. The deal was sealed with key government actors, industry and trade associations, and NGOs.

The agreement is divided into two phases: phase 1, from October 2019 to December 2020 , is to create working groups to establish the infrastructure and financial conditions for implementation; phase 2, scheduled to start in January 2021 and extend until 2025, will qualify service providers that will operate on this logistics system and develop communication and environmental education plans, aiming at the disclosure of this reverse system. The agreement's goal is to reach a rate of $17 \%$ for materials collected and correctly disposed of in 2025 .

The agreement prohibits the practice of commercialization, transfer, or other illegal action at the receiving points. It is worth noting the nonremuneration or payment for products discarded by consumers. Actor service providers will receive payments based on the type of electronic equipment received and processed, but this criterion of who, when, and how much are not yet clear in the agreement document. Large manufacturers and importers must correctly dispose of $100 \%$ of the products received by the reverse system. Retail trade should provide collection points, and legally constituted waste cooperatives can participate.

The agreement provides details of the collection, handling, transport, and storage of waste. The companies responsible for disassembly and separation must be licensed and legally authorized to carry out this process.

The public program is very detailed and has a sustainable vision, rather than a business one.

However, the current reality in Brazil is far from this framework. An informal chain of electronic waste collection and sale predominates in contrast to the low percentage of $3 \%$ of recycling that is legally carried out. This informal chain works according to the market and profit logic, which causes environmental impacts, since the non-reusable waste goes into landfill.

In addition, the size of this market is unknown. Data on the generation of electronic waste, both from international and Brazilian institutions, are created by inferring from the total annual production of legally established companies, which provide the data on the government. The institutions cross these numbers with the retail sales of electronics, creating the e-waste statistics. However, in Brazil, there is a vast informal market for electronics, either due to piracy or the remanufacturing of clandestine factories. This 
situation presents a challenge for research and management programs. How can we reach, account for, analyze, control, and modify this informal market?

In addition, the possible formal absence of assessment raises the question as to whether the actors, from consumers to separators, have sufficient commitment to and consciousness of sustainability to act in the proper manner, or whether they could deviate from the main objective. According to our interpretation, this is where the governance created by the actors themselves could be effective.

For example, a cooperative in a São Paulo neighborhood agreed with a condominium to collect e-waste, with a scheduled date and time. As the agreement was being fulfilled, other nearby condominiums joined the initiative. The city encouraged this type of agreement, because it eliminated the need for selective collection, thus obviating the need to pay third parties. It is in constructed governance, which considers the end/limit of connections, where change occurs.

The authors report that the systems for managing the production and disposal of electronic waste in Brazil are poorly developed, with a significant part of this waste going to landfills or going through informal chains that send the material to undetermined, sometimes even clandestine, locations $[47,64]$. With regulatory and inspection failures, the informal sector negotiates the most valuable components, discarding the rest in the environment without the necessary care. This situation is the reality, despite the determination of Brazil's solid waste law of the responsibility of producers to ensure that their waste products are sent to environmentally appropriate destinations [65].

According to our interpretation, a consciousness and disposition for collaboration and working together are lacking in São Paulo. In the next section, an analysis of the e-waste network in the city of São Paulo is conducted.

\section{The e-Waste Recycling Network in São Paulo}

This section describes the e-waste recycling network in São Paulo, based on secondary sources and data from technical interviews. Data from secondary sources were obtained from databases, such as online publications from the Yearbook of the National Association of Waste Pickers (https:/ / ancat.org.br/), Coopermiti website (http:/ / www.coopermiti. com.br/), Cedir/USP (https:/ / cetirp.sti.usp.br/lixo-eletronico/), and sites like the United Nations (https://nacoesunidas.org/secao/desenvolvimento-sustainable/), which make periodic global surveys on waste. Technical interview data were obtained through two presidents of cooperatives that deal with the task of waste disposal.

The criterion for selecting data was that they must refer to the problems, conflicts, solutions, and efficiency of networks, following the guidelines of verifying how the network is organized, which roles and functions are determined, which collective action mechanisms can be found, and whether there are signs of constructed governance.

The guiding proposition is that public programs that present complex characteristics, with unpredictable behaviors and conflicts, need constructed governance, which is capable of dealing with the necessary changes and adaptations in the network.

The data collected and organized on the e-waste recycling in São Paulo show a fragmented chain, with several ways of sending the collected material (to city hall centers, to cooperatives, or to intermediaries), various forms of dealing with the material (processes separation), and multiple destinations. Figure 1 shows the material flow, considering the basic points of the chain. Each point, for example, cooperatives and scrap dealers, is made up of several other organizations, which are either small, medium, large, certified, or illegal. Figure 1 shows a vast, multifaceted network with various tasks, functions, and objectives.

An example of a conflict between the ideal and the real situation is the case of a public company in the state of São Paulo that offers its electronic waste in an auction, in which the highest offered price wins the waste, irrespective of the destination of the material to be given by the buyer. The only precaution is to sign a term of commitment to comply with rules imposed by the environmental regulatory agency, which is to be signed at the end 
of the commercial process. In this case, it is possible to observe the business value, which firstly aims at financial gains and, only secondarily, at sustainable ones.

On the other hand, it was found that an e-waste recycling cooperative formed a small back-and-forth network in the network chain. The cooperative is certified (which is not easy in the state of São Paulo, due to the bureaucracy involved) and made partnerships with organizations that follow the disposal rules. Thus, interdependence between these organizations takes place in this cooperative. The cooperative dismantles the material, following all safety and sustainability standards, and has partnerships with buyers, who seek to assist the cooperative, following the rules regarding the transportation of waste to the correct destination and without engaging in abusive negotiations. It is a micronetwork within the broader network, which achieves sustainable results, social development (in support of the cooperative), and financial results.

All partnerships negotiated and discussed the rules to be implemented between the parties, constituting an example of constructed governance. The case indicates that constructed governance is an efficient way to recycle e-waste, following the threefold propeller of sustainable, social, and economic development.

Another example comes from the partnership between a university in the region of Campinas, close to São Paulo, a research center, and an e-waste recycling cooperative. The research center has developed tracking and material separation technologies, which are being tested in the newly formed cooperative, with financial support from the city government and scientific support from the university. It is an example of a technicalscientific partnership guided by the three pillars of sustainability, that is, sustainable actions (in the use of techniques that correctly separate materials), social development (giving employment to people who need it), and economic development (trading quality material with responsible companies).

These examples of micronetworks show a way to solve the problems associated with e-waste, although they are not strong enough to spread to the level of the broader network. Interviews with two presidents of such cooperatives reveal that in the city of São Paulo, there are no estimated data on the volume of electronic waste and the percentage of recycling, because there is no tracking and there are no data or reports on the transportation of waste from its production to its final destination. Other reasons for the lack of data include the strong presence of an informal network of collection points, street scavengers, organizations not authorized to separate materials, and an absence of rules in enterprises and apartment condos that require consumers to separate electronic waste from ordinary waste. These are elements that characterize the lack of a collective view of the network and predominance of the business view in São Paulo.

The evidence of the situation regarding e-waste disposal can be summarized as follows:

(a) The low efficiency in terms of the e-waste recycling rate, especially in large urban centers in Latin America, such as São Paulo;

(b) The problems associated with the distance between laws and practices in countries, especially commercial practices that are far from sustainable objectives;

(c) The lack of use of tracking technologies and material separation processes;

(d) The complex, multifaceted networks, with numerous distinct subnets;

(e) The examples of micronetworks that create rules between different parties.

Using an abductive methodology, adding the facts and the assumptions to a logical framework, a model for the analysis and management of e-waste is proposed, with constructed governance as the principal axis. The next section describes the framework, the propositions/hypotheses, and the theoretical foundations. 


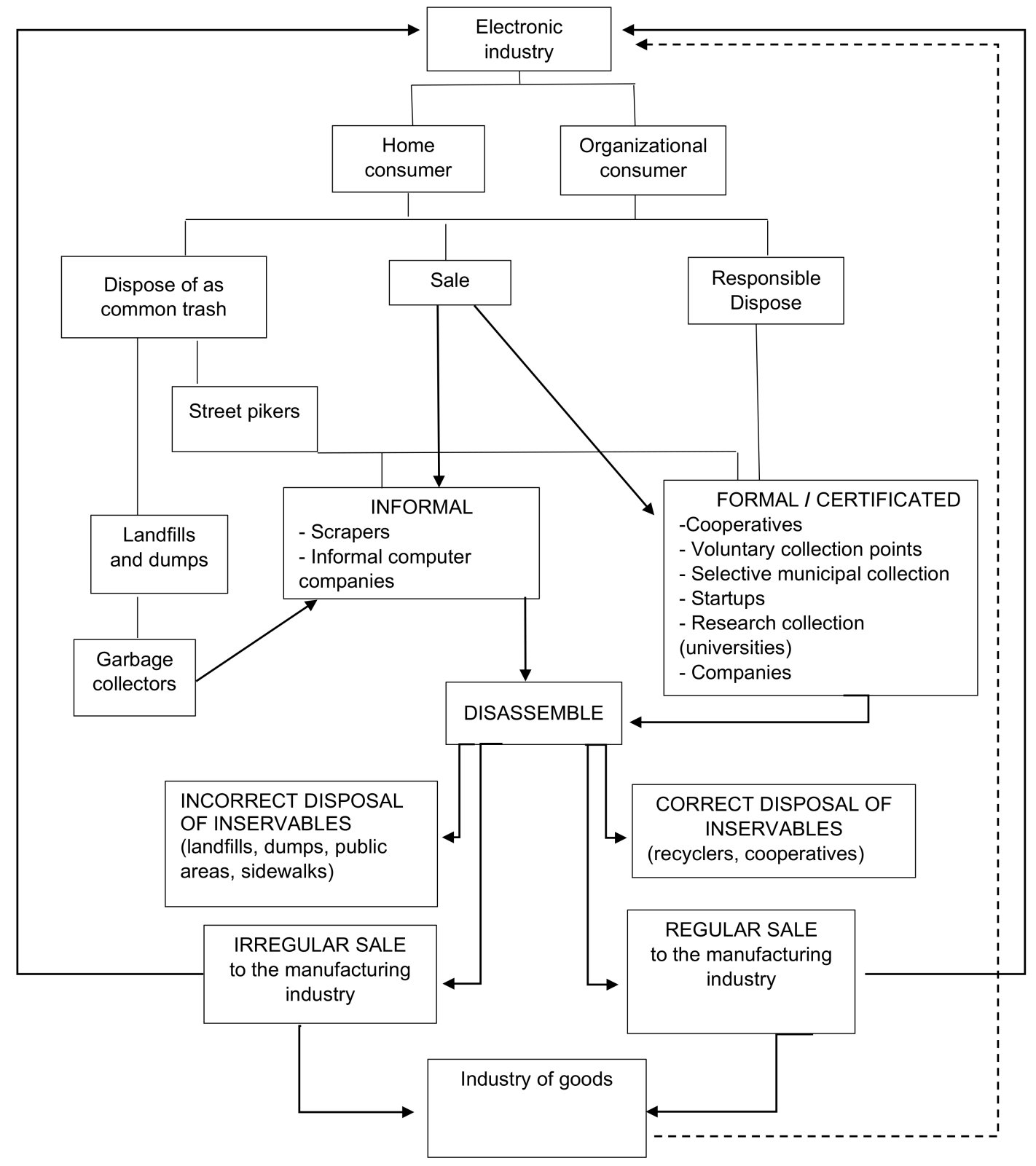

Figure 1. e-Waste recycling flow.

\section{The Constructed Governance Model}

To provide theoretical support for the constructed governance model applied to the analysis and management of e-waste recycling, the social foundations of networks were selected. The first theoretical basis is the relational view [66,67], that is, the principle that business strategies and the implementation and success of public tasks can be understood from the relationship matrix between the actors. As a derived statement, it is affirmed that the construction and development of networks are founded on social relationships of collaboration, trust and commitment [68].

Trust is defined as depending on another because a task cannot be accomplished alone. Commitment is defined as the other side of the coin of trust, that is, helping the other who needs and trusts you, placing the collective goals above the individual, and not taking advantage of the dependence situation of the other to obtain advantages $[33,69]$.

The predominance of these forms of relationship in a group allows for the conditions required for discussion, decisions, and organizations relating to a collective task, that is, 
constructed governance. The relational view and the relationship environment are the basis of the first proposition of the model:

A1. The constructed governance model applied to e-waste recycling management needs a cooperative environment among the participants, with a predominance of trust and commitment. The dominance of competitive relationships, or a lack of commitment to collective actions, makes it difficult, or even impossible, to develop constructed governance.

The second theoretical foundation refers to the solution of possible conflicts caused by asymmetries. Asymmetrical conflict is defined as any difference between actors that may interfere with a group's task [39-41]. The conflicts most often cited in the literature relate to (a) interests; (b) objectives; (c) opposition between behavior aimed at collective tasks and that aimed at individual results; (d) differences in commitment and cooperation between actors in the network; (e) disputes over resources, rather than sharing of resources; and (f) tensions regarding roles and functions in the group.

Part of group work efficiency depends on how these conflicts are solved [70] and academic literature points out some of these solutions: (i) collaboration and coordinated efforts among organizational actors [71]; (ii) development of an adequate communication network [54]; (iii) fast organizational knowledge transfer and learning; (iv) orientation toward cohesion; (v) ethical management; (vi) choosing the right actors to solve the right problems; (vii) choosing the best management approach for each relational conflict, for example, avoiding, integrating, gathering, and compelling [53]; (viii) focusing on competitors, taking the focus off internal problems [53]; (ix) visualizing the asymmetry as a whole in the group and not just part [72].

The solutions from (i) to (v) are collective modes, requiring all actors in the making of decisions, which characterizes the construction of governance. The solutions from (vi) to (ix) are about management and can be carried out collectively or by a single decision-maker.

The second proposition derives from the concepts and discussion of asymmetry, conflicts, and solutions:

A2. The constructed governance model applied to e-waste recycling management is a way of solving conflicts caused by asymmetries, thus influencing the efficiency of the task. For each conflict, unexpected situation, or demand that requires a solution, mechanisms, rules, and practices are created, which are oriented toward improving the efficiency of the group. The construction of these mechanisms is the collective social process, named constructed governance.

The third theoretical foundation is the concept of constructed governance, developed by the authors of this work. Governance is defined as the set of mechanisms that guide, control, and encourage collective action [28,73]. The governance adopted in a group can be formal, that is, based on laws, rules, and guidelines that already exist in the organizational field. The authors agree that formal governance is not able to solve all the problems and unforeseen circumstances of a group, especially since each group, in each situation, has distinct experiences $[34,74]$. In these cases, the literature refers to informal governance, meaning the mechanisms' adjustments according to the group's needs $[75,76]$.

Collaborative governance and relational governance are expressions that refer to informal governance. Collaborative governance is predominantly defined as the government's ability to attract stakeholders to collective work [49]. Relational governance is mainly defined as rules and controls that arise due to trust and commitment relations (which is practically the same as our definition of the concept of informal governance).

According to our interpretation, these divisions (formal or informal, collaborative, and relational) are partial and insufficient to explain the social construction of the mechanisms in e-waste recycling networks. The division between formal and informal governance carries the logical difficulty of describing how rules and practices that are formed through informal experiences over time are legitimized and formalized. In order to describe informal governance, it will be necessary to use arguments from institutional theory [77], that cannot be found in academic publications. Collaborative governance, in the sense of 
attracting stakeholders, and relational governance, in the sense of controlling opportunistic behavior by social relations, are, in our view, necessary conditions for the emergence of constructed governance. Still, they do not explain the process of each constructed norm or rule.

If these conditions of collaborative governance and relational governance exist, there are collective decision-making processes for deciding the mechanisms and the ways to implement them. Through this social construction process, the network organization arises. The actors determine the content of the rules (for example, a determined company that generates waste will distribute $50 \%$ of its material to authorized cooperatives and $50 \%$ to market buyers), the form of control (for example, the cooperative participates in the group within the company that takes care of the destination of the material), and the objective to be achieved (for example, a sustainable destination for the material + the social inclusion of members in the decisions + legal, market, and image advantages for the company that generates the waste).

Constructed governance is defined as the mechanisms that are created by the group itself, as distinct from the mechanisms that already exist in the organizational field (such as laws, market rules, or ready-made tools of consulting groups), which emerge and take place when participants are willing to collaborate, and there is a relationship environment that allows for the discussion and solution of conflicts and demands.

This construction occurs over time through the learning and cooperation involvement of actors, which reinforces trust, credibility, and commitment, thus legitimizing and encouraging continuity of collaboration $[35,78]$. From the comments in the previous paragraphs, the third proposition of the model may be put forward:

A3. Constructed governance is an alternative and efficient way to solve conflicts and establish a framework that guides the structure of roles and functions in a group. The types of collective work and the whole process are made and legitimized by the group itself. The cohesion and efficiency of the group are achieved by the members, who together decide the mechanisms that will govern their mode of action. The logic is that if they created the mechanisms themselves, resistance and disobedience will be minimal.

As stated, literature on the constructed network governance process is rare. Group decisions are a theme of group dynamics, which is the next theoretical foundation. Concepts of group dynamics are rare in discussions about network governance. Still, researchers in the fields of social psychology, sociology, and anthropology [79-82] are agreed that group cohesion is more easily achieved when the participants decide the rules than when they are imported into the group. This occurs for two basic reasons:

(a) Imported rules may not be adequate to the group and task characteristics, thus requiring adjustments;

(b) Participation in the decision of the rules develops responsibility and commitment in the actors, both in following the rules and in controlling those who do not follow them.

The fourth proposition is derived from this principle:

A4. When the actors of a group actively participate in constructing the rules, attitudes of responsibility and commitment emerge, which fosters compliance with the rules and group cohesion. The logic is that if the actors created the mechanisms themselves, then the rules will be followed and, by inference, results will be achieved.

Achieving results is the goal of any management action. If constructed governance contributes to achieving results, it can be the object of attention and action for managers. This is indicated in the fifth proposition:

A5. Constructed governance is an important social process to be considered by managers of recycling sustainability programs, because it influences the conditions of organization and functionality of networks and, consequently, achieves results.

Table 4 shows the propositions that support the association between constructed governance and management. 
Table 4. Statements that support the association between constructed governance and management.

\begin{tabular}{|c|c|c|}
\hline Statement & Origin & Interface with Managerial Actions \\
\hline $\begin{array}{l}\text { A1. The constructed governance model applied } \\
\text { to e-waste recycling management needs a } \\
\text { cooperative environment among the } \\
\text { participants, with a predominance of trust and } \\
\text { commitment. }\end{array}$ & $\begin{array}{l}\text { The dominant relationship } \\
\text { environment between network } \\
\text { participants determines part of the } \\
\text { group's functionality }\end{array}$ & $\begin{array}{c}\text { Create an environment with predominance } \\
\text { of relationships of trust and commitment, } \\
\text { assisting in the emergence of built } \\
\text { governance. }\end{array}$ \\
\hline $\begin{array}{l}\text { A2. The constructed governance model applied } \\
\text { to e-waste recycling management is a way of } \\
\text { solving conflicts caused by asymmetries, } \\
\text { influencing the efficiency of the task. }\end{array}$ & $\begin{array}{l}\text { Conflicts generated by asymmetries, } \\
\text { such as interests, or willingness to } \\
\text { take collective action, can impair the } \\
\text { network's functionality. }\end{array}$ & $\begin{array}{l}\text { Managers help the group to find ways to } \\
\text { reduce the impact of conflicts caused by } \\
\text { asymmetries, seeking functionality and } \\
\text { efficiency for the group. }\end{array}$ \\
\hline $\begin{array}{l}\text { A3. Constructed governance is an alternative } \\
\text { and efficient way to solve conflicts and } \\
\text { establishing a framework that guides the } \\
\text { structure of roles and functions in a group. The } \\
\text { ways of collective work and the whole process is } \\
\text { made and legitimized by the group itself. }\end{array}$ & $\begin{array}{c}\text { Formal governance is not sufficient } \\
\text { and adequate because each group has } \\
\text { its characteristics, requiring } \\
\text { adjustments. }\end{array}$ & $\begin{array}{l}\text { Managers assist the actors in the creation } \\
\text { and implementation of the rules and } \\
\text { functioning of the group, seeking cohesion } \\
\text { and control of the actions, which influences } \\
\text { in obtaining results. }\end{array}$ \\
\hline $\begin{array}{c}\text { A4. When the actors of a group actively } \\
\text { participate in constructing the rules, attitudes } \\
\text { of responsibility and commitment emerge, } \\
\text { which helps comply with the rules and the } \\
\text { group's cohesion. }\end{array}$ & $\begin{array}{l}\text { Imported formal mechanisms can } \\
\text { generate resistance and } \\
\text { disagreements between the actors. } \\
\text { The adjustment made by the actors, } \\
\text { according to the specificity of each } \\
\text { group, solves some of these problems. }\end{array}$ & $\begin{array}{l}\text { The managers assist the actors in the } \\
\text { disposition for cooperative actions, both in } \\
\text { modes of operation and in modes of } \\
\text { control, developing embeddedness and } \\
\text { responsibility. Thus, formal governance, } \\
\text { necessary concerning laws and standards } \\
\text { in e-waste, coexists with constructed } \\
\text { governance }\end{array}$ \\
\hline $\begin{array}{l}\text { A5. Constructed governance is an important } \\
\text { social process to be considered by managers of } \\
\text { recycling sustainability programs because it } \\
\text { influences the conditions of organization and } \\
\text { functionality of the networks and, consequently, } \\
\text { in obtaining results. }\end{array}$ & $\begin{array}{l}\text { Many actors participate in public } \\
\text { services with different objectives, } \\
\text { knowledge, and attitudes, and the } \\
\text { constructed governance aligns } \\
\text { disagreements because the actors } \\
\text { themselves unite in creating the rules. }\end{array}$ & $\begin{array}{l}\text { Without neglecting the traditional factors } \\
\text { that drive the actions of managers, such as } \\
\text { resources, operations, and strategy, it is } \\
\text { stated that the constructed governance is an } \\
\text { important social process in public policies } \\
\text { for network functionality and obtaining } \\
\text { results and should be considered in the } \\
\text { management plan in e-waste recycling. }\end{array}$ \\
\hline
\end{tabular}

The proposition can be seen in a graphical form in Figure 2.

The next section presents how the proposed model could be applied to the real situation in São Paulo. 


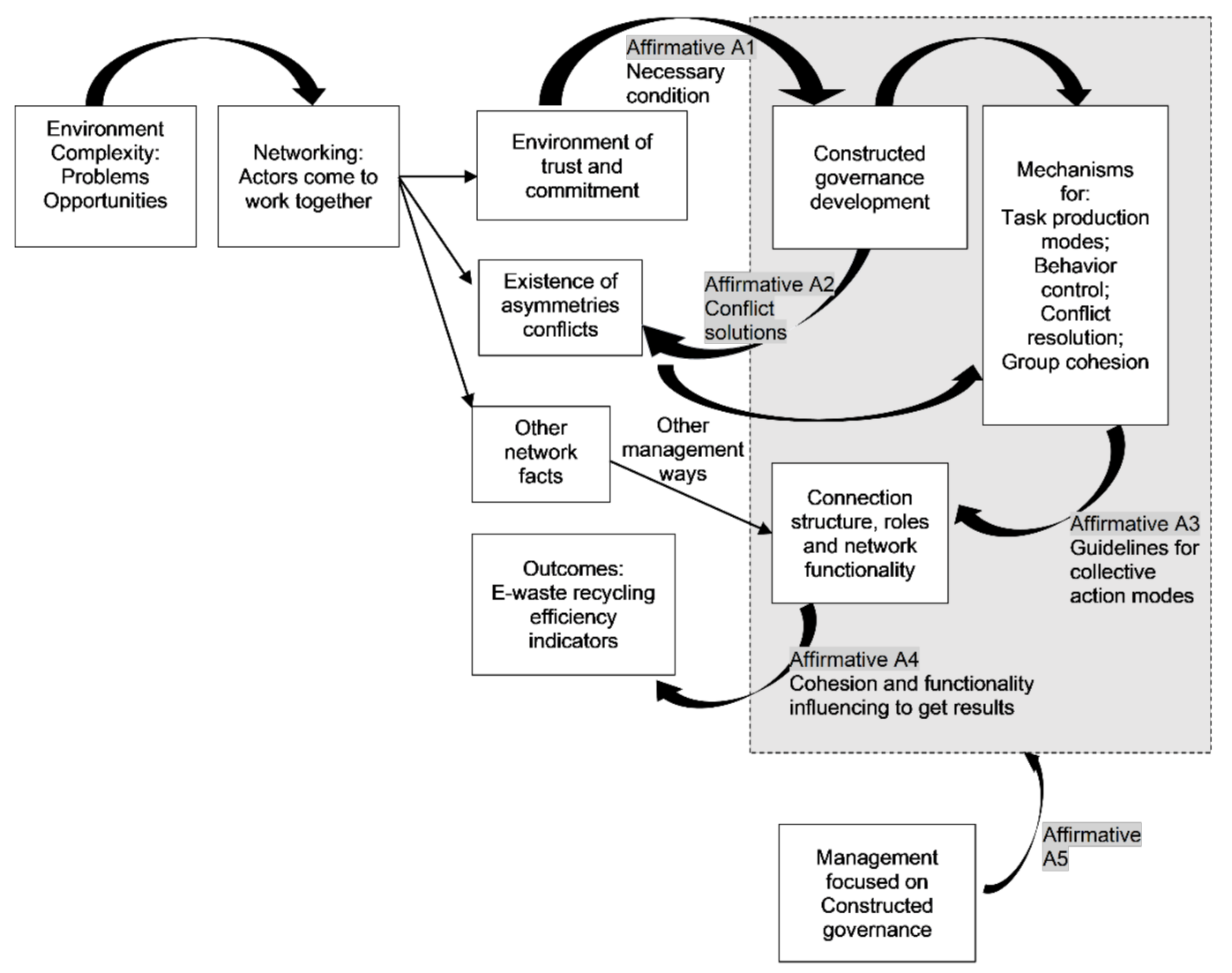

Figure 2. The proposition model of constructed governance influencing outcomes.

\section{Discussion: Management Challenges and Opportunities in the e-Waste Recycling Network in São Paulo}

The relevant point for e-waste cases is that the task of e-waste disposal can only be solved through collective action because of the complexities, such as the collection, destination, separation, and new destination of unusable material. The presence of task complexity, interdependence, the necessity for cooperation, and the necessity for a type of governance that can influence the ways in which the task can be completed, is typical of the network format $[46,83]$.

The first challenge of an e-waste management program is the construction (if it does not exist) of strong ties that enable collective actions. Studies on network management $[84,85]$ suggest that the first step is to develop collective action awareness and clearly show how the collective action brings benefits and not problems for each participant. It is assumed that managers know the basic principles of the formation and dynamics of groups.

In the case of São Paulo city, successful examples of micronetworks could serve as a stimulus for this challenge of raising awareness and acceptance of collective actions. Clarifying the legal and market advantages for those who follow the sustainability rules linked to the 2030 Agenda can also be used to foster compliance [86,87].

The second challenge is to develop an environment of cooperation that prevails over the logic of competition. Whatever the differences or asymmetries among the actors, the manager must strive to obtain the commitment of the participants, making it clear that the success of the group causes the success of each individual participant.

In the case of São Paulo City, where the market/profit logic seems to prevail, it would be a case of developing local partnerships (in restricted regions) where there are large suppliers of electronic waste (such as universities and public-private companies that deal with electronic tasks, such as supply and transport systems). It could seem a challenging task, but the cases described here show that it is possible. The manager could 
use technological resources to create a group, for example, to discuss the theme of e-waste management and encourage people to join it, just as is suggested by authors [88].

Having created these initial conditions, the model assumes that the actors will initiate conversations and decide how to act together, which puts constructed governance in motion. At this step, the asymmetrical conflicts about the content of the rules, roles, and modes to produce the service arise. According to the group dynamics principles, a group's cohesion depends on the task's characteristics (i.e., the level of necessity to work together) and the relational matrix created in the early steps.

The discussion developed in this article shows that scientific and public management research on e-waste can use a two-order matrix of indicators: (a) asymmetrical conflicts; and (b) constructed governance.

Considering the characteristics of the e-waste recycling network, the following indicators appear to be the most important:

i. Asymmetry in commitment to collective actions;

ii. Asymmetry in collective opposition of private interests;

iii. Asymmetry in attitudes towards sustainability or business;

iv. Asymmetry in information about waste collection and destination;

v. Asymmetry in (absence of) controls and punishments;

vi. Power asymmetries (especially in manufacturers).

These conflicts/problems appeared to be consistent with the data analysis. To search for solutions, the following indicators of constructed governance appeared to be realistic, possible, and operational solutions.

A. Agreements between organizations and individuals within a micro-region on how to carry out a task, according to the reality regarding local resources. Examples placed in the article show that this action is possible and that attempts have been made to solve this asymmetry (i).

B. Agreements between government and businessmen to adapt the formal rules of responsibility for e-waste, offering a trade-off, which does not exist nowadays. These agreements, which may be local, especially combat asymmetries (ii), (v), and (vi).

C. Arrangements between manufacturers, retailers, governments, and society to correctly dispose of e-waste, which are currently dispersed in legal and illegal areas and points. There are examples of such actions, for example, cell phones and refrigerators, which involve great compromises at the level of society but for limited periods of time. The challenge is to make agreements without an end point. This action combats asymmetries (i), (iii), and (iv).

D. Technology and traceability developments. For reasons that would lead to further investigation, there is little technology for collecting, treating, and reusing e-waste. These actions need to be taken by the government, and technological innovation hubs can assist in the development of technological projects aimed at completing this task. Governments, companies, and technology hubs would benefit from such constructed governance between them.

E. As a result of the previous solution, integrated actions between companies, cooperatives, and governments to disseminate e-waste disposal, collection, and correct reuse efforts to all media and audiences, accompanied by how-to programs in schools, neighborhoods, or regions, could lessen the impact of knowledge and information asymmetry.

If the managers reach this point in developing constructed governance, results start to appear. The logistics of collection, shipping, separation, and transportation of waste to the correct destination are set in motion. Sustainable, social, and economic results become evidence of feedback from the system $[89,90]$. According to the proposition regarding the spiral spread of facts in networks [91,92], a good example can spread in the network and become a model to be used for all the actors. Simultaneously, the hierarchical/formal governance clarifies the rights and limits relating to each action. 
Supposing the manager could obtain such examples, he/she could spread them in the network and ask the actors to control any opportunistic behavior that is not in accordance with the sustainable way of discharging electronic waste. In that case, the principles of results and efficiency are planted.

\section{Conclusions}

E-waste is a big problem because of its increase in volume and because of the failure of public management strategies to attack and solve the problem, which is very important. The rate of e-waste recycling is only around $17.4 \%$ in the world, $11 \%$ in Latin America, and 3\% in São Paulo. This is clear evidence of the necessity to review and improve the management models. Most of them are based on control, hierarchical governance, and the prohibition of commercial actions, but the numbers show that this way seems not to be successful.

This is the challenge faced by the present article. We analyze the characteristics of e-waste recycling networks, searching for common problems around the world, and offer an alternative for thinking and acting in the field through an abductive methodology.

The analysis of São Paulo city, the largest producer of e-waste in Latin America, shows that constructed governance could be a competent way to bring actors together to decide about collective rules and obtain a high volume of recycled material, compared with the actual numbers. Unlike formal and hierarchical governance, constructed governance is a collective process in which the actors directly involved in a task join together to discuss and solve their asymmetries, decide their objectives, and produce a service. This is the core process behind the expression, "constructed".

The analysis of constructed governance examples in the e-waste network in São Paulo pointed out that this process is possible in small groups because of the necessity for strong ties, trust, and constant meetings. However, this limit concerning the group size is not necessary throughout the entire network, because the experience can spread along the network spiral, until it becomes an accepted model that is used by the actors.

We present a model with theory and indicators to develop constructed governance. Our proposition goes a step away from collaborative governance, which is related to efforts to join actors, and relational governance, which is associated with creating an optimal environmental relationship. It is affirmed that these two expressions refer to the necessary but not sufficient conditions to be applied to the entire complexity of joining actors, solving differences, coming to agreements on collective mechanisms, and implementing them. It is a complete cycle of group dynamics.

This theoretical result is accomplished by a methodological one. Table 4 and Figure 2 show how to plan and conduct new research with constructed governance as the central category. In terms of the data collection technique, the researcher needs to follow the history of group dynamics, considering the construction, implementation, and results of collective mechanisms in terms of the tasks and terms of the spread in the network.

The investigation carried out in this article, which basically involved collecting data from secondary sources, shows the problems and possible solutions for São Paulo City. The evidence shows the same issues that are present throughout the world, but some examples of success are available, which give a direction for further research:

(a) The rate is low because there are logical conflicts relating, for example, to following the logic of profit and/or the logic of sustainability; conflicts of interest; and unsolved asymmetries about power, inspection, objectives, and knowledge. Because of this, most e-waste is not tracked.

(b) Concerning logical conflicts, the profit logic prevails in such a way that actors do not follow sustainability rules. This situation remains practically untouchable because of the lack of control and the lack of compromise in relation to sustainable principles.

(c) The existence of formal governance and the reality of the market practice in São Paulo indicate that there is an ideal world in documents and laws, which is focused on 
sustainability, but there is also a real-world, which is quite different and focused on the market, price, and profit.

(d) Examples of small groups organized to follow the sustainability rules show that the results could be much better. These groups have constructed their own rules about how to do their jobs, while always following the paths of sustainability, especially the reuse and transportation of waste to the right destination. These examples indicate that there is no incompatibility between sustainability rules and profit.

What is the lesson to be learned from the foregoing? Formal governance is not sufficient to achieve an e-waste recycling network with an excellent performance. The examples of small groups show that it is possible to go one step further through a social process of constructing governance that is aligned with the laws. The group dynamic theory gives the logic and the basis to affirm that when the actors of a group decide on their rules, they learn how to compromise and self-control. Under these conditions, the group becomes operational and obtains better results. This social process is constructed governance.

The constructed governance concept could impact public programs, usually based on control, rules, and technical details, thus opening a new avenue for developing relationships. Japan is a good example of this, because in each neighborhood, residents follow government rules, yet they also agree on who can help by being a garbage inspector or teaching people how to separate products [93]. This is constructed governance.

The theoretical propositions presented in this paper offer an alternative way to understand the success or failure of public recycling policies. We propose that theories of resources, agency theory, and stakeholder theory are not sufficiently explanatory, their application is limited, and they do not obtain results because they start from a division unit (individual or organization), which is set against the environment. The constructed governance concept starts from a systemic and integrated view of people, organizations, and the environment. It is always about people engaging in relationships to complete tasks.

Figure 2 shows the impact of the methodology. The article offers a way to plan research on public policy results based on understanding the relationships between actors, rather than the routines and functions that are the hallmark of programs run by the government. The relational view is a well-known and accepted paradigm in the field of networks, but, until now, it has rarely been used in research.

The model proposes a way of managing e-waste recycling that can be added to the other traditional modes of management concerning managerial impact. It is not suggesting as a unique model. Still, based on real cases, the focus on constructed governance has the logic and consistency to constitute a path that can assist in public policies. This allows managers to pay attention to small groups' social processes and opens up the possibility to improve programs of collective actions. The success of a small group could be spread to all networks.

Such efforts are justified because of the great global challenge that waste poses. There are examples, good and bad, about the sustainability from every part of the planet. Waste on the earth, in oceans, in rivers, and in lakes challenge environmentalists to determine how to minimize the problem. The 2030 Agenda is very clear about the challenges directly related to waste: 6 . Clean water and sanitation; 11 . Sustainable cities and communities; 12. Responsible consumption and production; 14. Life below water; and 15. Life on land.

Related to the theme of e-waste, these SDGs goals are connected with the following levels of accountability: (a) corporate social responsibility, i.e., to transport generated e-waste to a correct destination, which is one of the challenges in the e-waste network; (b) large companies' responsibility, i.e., to ensure that their production of e-waste can support the operation of recycling cooperatives in accordance with the law of each country, to make sure that the material reaches a correct destination, and to pursue the social objective of sustainability; and (c) the increasing volume of e-waste in the world indicates that a specific plan is necessary, apart from solid waste, because it contains complexities that are specific and follow a different path in the circular economy. 
We invite researchers to collect more and more examples of constructed governance. Such examples do exist, but they need to be reported, so that the direction in the research on this topic may turn toward relationships, rather than processes or results.

Author Contributions: Conceptualization, F.P., E.G.; Data curation, L.V., N.M.; Formal analysis, N.M.; Investigation, F.P., E.G.; Methodology, F.P. and L.V.; Supervision, E.G.; Validation, F.P., E.G., L.V. and N.M.; Writing—original draft, F.P.; Writing—review \& editing, E.G., L.V. and N.M. All authors have read and agreed to the published version of the manuscript.

Funding: This research received no external funding.

Institutional Review Board Statement: Not applicable.

Informed Consent Statement: Not applicable.

Data Availability Statement: No new data were created or analyzed in this study. Data sharing is not applicable to this article.

Conflicts of Interest: The authors declare no conflict of interest.

\section{References}

1. Forti, V.; Baldé, C.P.; Kuehr, R.; Bel, G. The Global E-Waste Monitor 2020: Quantities, Flows, and the Circular Economy Potential; United Nations University: Bonn, Germany, 2020.

2. Cruz-Sotelo, S.E.; Ojeda-Benítez, S.; Sesma, J.J. E-waste supply chain in Mexico: Challenges and opportunities for sustainable management. Sustainability 2017, 9, 503. [CrossRef]

3. Balde, C.P.; Forti, V.; Gray, V.; Kuehr, R.; Stegmann, P. The Global E-Waste Monitor 2017; United Nations University: Bonn, Germany, 2017.

4. $\quad$ ABRELPE. Panorama Dos Resíduos Sólidos No Brasil 2018/2019; Abrelpe: São Paulo, Brazil, 2019.

5. Mihai, F.C.; Gnoni, M.G.; Meidiana, C.; Ezeah, C.; Elia, V. Waste electrical and electronic equipment (WEEE): Flows, quantities, and management-a global scenario. In Electronic Waste Management and Treatment Technology; Butterworth-Heinemann Ed.: Oxford, UK, 2019.

6. Boeni, H.; Silva, U.; Ott, D. E-waste recycling in Latin America: Overview, challenges and potential. In Proceedings of the 2008 Global Symposium on Recycling, Waste Treatment and Clean Technology, REWAS 2008, Cancun, Mexico, 12-15 October 2008.

7. Redondo, J.M.; Ibarra-Vega, D.; Monroy, L.; Bermúdez, J. Assessment strategies for the integral management of waste electrical and electronic equipment-WEEE. DYNA 2018, 85, 319-327. [CrossRef]

8. Ongondo, F.O.; Williams, I.D.; Cherrett, T.J. How are WEEE doing? A global review of the management of electrical and electronic wastes. Waste Manag. 2011, 31, 714-730. [CrossRef]

9. Margallo, M.; Ziegler-Rodriguez, K.; Vázquez-Rowe, I.; Aldaco, R.; Irabien, Á.; Kahhat, R. Enhancing waste management strategies in Latin America under a holistic environmental assessment perspective: A review for policy support. Sci. Total Environ. 2019, 689, 1255-1275. [CrossRef] [PubMed]

10. Velázquez, L.; Munguía, N.; Zavala, A.; Navarrete MDLÁ. Challenges in operating sustainability initiatives in Northwest Mexico. Sustain. Dev. 2008, 16, 401-409. [CrossRef]

11. Cordova-Pizarro, D.; Aguilar-Barajas, I.; Romero, D.; Rodriguez, C.A. Circular economy in the electronic products sector: Material flow analysis and economic impact of cellphone e-waste in Mexico. Sustainability 2019, 11, 1361. [CrossRef]

12. Vanderlei, C.A.; Kniess, C.; Quoniam, L. Patent technometry by mind maps: A study on the recycling of waste electrical and electronic equipment. Int. J. Innov. 2020, 8, 77-100. [CrossRef]

13. Kahhat, R.; Williams, E. Materials flow analysis of e-waste: Domestic flows and exports of used computers from the United States. Resour. Conserv. Recycl. 2012, 67, 67-74. [CrossRef]

14. Sinha-Khetriwal, D.; Kraeuchi, P.; Schwaninger, M. A comparison of electronic waste recycling in Switzerland and in India. Environ. Impact Assess. Rev. 2005, 25, 492-504. [CrossRef]

15. Ryen, E.G.; Gaustad, G.; Babbitt, C.W.; Babbitt, G. Ecological foraging models as inspiration for optimized recycling systems in the circular economy. Resour. Conserv. Recycl. 2018, 135, 48-57. [CrossRef]

16. Awasthi, A.K.; Wang, M.; Awasthi, M.K.; Wang, Z.; Li, J. Environmental pollution and human body burden from improper recycling of e-waste in China: A short-review. Environ. Pollut. 2018, 243, 1310-1316. [CrossRef]

17. Federico, M.; Kuehr, R.; Baldé, C. eWaste en América Latina: Statistical Analysis and Policy Recommendations; GSMA: Tokyo, Japan, 2015.

18. Ardi, R.; Leisten, R. Assessing the role of informal sector in WEEE management systems: A System Dynamics approach. Waste Manag. 2016, 57, 3-16. [CrossRef]

19. Xue, W.; Cao, K. Optimal routing for waste collection: A case study in Singapore. Int. J. Geogr. Inf. Sci. $2016,30,554-572$. [CrossRef]

20. Campos, H.K.T. Recycling in Brazil: Challenges and prospects. Resour. Conserv. Recycl. 2014, 85, 130-138. [CrossRef] 
21. Medina, M. The informal recycling sector in developing countries. Grid Lines 2008, 44, 1-4.

22. Mativenga, P.T.; Agwa-Ejon, J.; Mbohwa, C.; Sultan, A.A.M.; Shuaib, N.A. Circular Economy Ownership Models: A view from South Africa Industry. Procedia Manuf. 2017, 8, 284-291. [CrossRef]

23. Milovantseva, N.; Saphores, J.D. E-waste bans and U.S. households' preferences for disposing of their e-waste. J. Environ. Manag. 2013, 124, 8-16. [CrossRef] [PubMed]

24. Kucukvar, M.; Egilmez, G.; Tatari, O. Evaluating environmental impacts of alternative construction waste management approaches using supply-chain-linked life-cycle analysis. Waste Manag. Res. 2014, 32, 500-508. [CrossRef] [PubMed]

25. Robertson, M. Waste and Recycling. In Sustainability Principles and Practice; Routledge: London, UK, 2018.

26. Pickren, G. Political ecologies of electronic waste: Uncertainty and legitimacy in the governance of e-waste geographies. Environ. Plan. A 2014, 46, 26-45. [CrossRef]

27. Nzeadibe, T.C.; Anyadike, R.N.C. Social participation in city governance and urban livelihoods: Constraints to the informal recycling economy in Aba, Nigeria. City Cult. Soc. 2012, 3, 313-325. [CrossRef]

28. Liu, Z.; Zhang, Q. The Effects of Interorganizational Systems on Relational Governance in the Manufacturer-supplier Relationship. Contemp. Logist. 2013, 11, 55-62.

29. Gorod, A.; Hallo, L.; Nguyen, T. A Systemic Approach to Complex Project Management: Integration of Command-and-Control and Network Governance. Syst. Res. Behav. Sci. 2018, 35, 811-837. [CrossRef]

30. Lusugga Kironde, J.M.; Yhdego, M. The governance of waste management in urban Tanzania: Towards a community based approach. Resour. Conserv. Recycl. 1997, 21, 213-226. [CrossRef]

31. Hettiarachchi, H.; Ryu, S.; Caucci, S.; Silva, R. Municipal solid waste management in Latin America and the Caribbean: Issues and potential solutions from the governance perspective. Recycling 2018, 3, 19. [CrossRef]

32. Wilson, D.C.; Velis, C.A.; Rodic, L. Integrated sustainable waste management in developing countries. Waste Resour. Manag. 2013, 166, 52-68. [CrossRef]

33. Ansell, C.; Gash, A. Collaborative governance in theory and practice. J. Public Adm. Res.Theory 2008, 18, 543-571. [CrossRef]

34. Gash, A. Cohering Collaborative Governance. J. Public Adm. Res. Theory 2017. [CrossRef]

35. Emerson, K.; Nabatchi, T.; Balogh, S. An integrative framework for collaborative governance. J. Public Adm. Res. Theory 2012, 22, 1-29. [CrossRef]

36. Huxham, C.; Vangen, S.; Huxham, C.; Eden, C. The Challenge of Collaborative Governance. Public Manag. Int. J. Res. Theory 2000, 2, 337-358. [CrossRef]

37. Johnston, E.W.; Hicks, D.; Nan, N.; Auer, J.C. Managing the inclusion process in collaborative governance. J. Public Adm. Res. Theory 2011, 21, 699-721. [CrossRef]

38. Piatak, J.; Romzek, B.; LeRoux, K.; Johnston, J. Managing Goal Conflict in Public Service Delivery Networks: Does Accountability Move Up and Down, or Side to Side? Public Perform. Manag. Rev. 2018, 41, 152-176. [CrossRef]

39. Mathews, M. Managing local supplier networks: Conflict or compromise? Reg. Stud. 2018, 52, 890-900. [CrossRef]

40. Hernández, P.; Martínez-Cánovas, G.; Muñoz-Herrera, M.; Sánchez, A. Equilibrium characterization of networks under conflicting preferences. Econ. Lett. 2017, 155, 154-156. [CrossRef]

41. Siddiki, S.; Kim, J.; Leach, W.D. Diversity, Trust, and Social Learning in Collaborative Governance. Public Adm. Rev. 2017, 77, 863-874. [CrossRef]

42. Weerasundara, L.; Mahatantila, K.; Vithanage, M. E-Waste as a Challenge for Public and Ecosystem Health. Available online: http:/ / dr.lib.sjp.ac.lk/bitstream/handle/123456789/9098/Weerasundra\%202020.pdf?sequence=1\&isAllowed=y (accessed on 21 December 2020).

43. Pandey, P.; Govind, M. Socio-technological challenges in formalization of E-waste recycling in India. In Handbook of Electronic Waste Management; Butterworth-Heinemann: Oxford, UK, 2020; pp. 243-262.

44. Peng, B.; Tu, Y.; Wei, G. Governance of electronic waste recycling based on social capital embeddedness theory. J. Clean. Prod. 2018, 187, 29-36. [CrossRef]

45. Toumi, O.; Le Gallo, J.; Ben Rejeb, J. Assessment of Latin American sustainability. Renew. Sustain. Energy Rev. 2017, 78, 878-885. [CrossRef]

46. Giglio, E.M.; Ryngelblum, A.; Lopes de Sousa Jabbour, A.B. Relational governance in recycling cooperatives: A proposal for managing tensions in sustainability. J. Clean. Prod. 2020, 260, 121036. [CrossRef]

47. Bhaskar, K.; Kumar, B. Electronic waste management and sustainable development goals: Is there a business case for linking the two? J. Indian Bus. Res. 2019. [CrossRef]

48. Börner, L.; Hegger, D.L.T. Toward design principles for sound e-waste governance: A research approach illustrated with the case of the Netherlands. Resour. Conserv. Recycl. 2018, 134, 271-281. [CrossRef]

49. Klijn, E.H.; Koppenjan, J. Governance Networks in the Public Sector; Routledge: London, UK, 2015. [CrossRef]

50. Kerr, N.L.; Tindale, R.S. Group performance and decision making. Annu. Rev. Psychol. 2004, 55, 623-655. [CrossRef]

51. Srba, I.; Bielikova, M. Dynamic group formation as an approach to collaborative learning support. IEEE Trans. Learn. Technol. 2015. [CrossRef]

52. McPherson, J.M.; Popielarz, P.A.; Drobnic, S. Social Networks and Organizational Dynamics. Am. Sociol. Rev. 1992. [CrossRef]

53. Sorenson, R.L. Conflict management strategies used by successful family businesses. Fam. Bus. Rev. 1999, 12, 325-340. [CrossRef]

54. Spaho, K. Organizational communication and conflict management. Management 2013, 18, 103-118. 
55. Bergsten, A.; Jiren, T.S.; Leventon, J.; Dorresteijn, I.; Schultner, J.; Fischer, J. Identifying governance gaps among interlinked sustainability challenges. Environ. Sci. Policy 2019, 91, 27-38. [CrossRef]

56. Sorensen, L.J.; Stanton, N.A. Keeping it together: The role of transactional situation awareness in team performance. Int. J. Ind. Ergon. 2016, 53, 267-273. [CrossRef]

57. Ratner, B.D.; Meinzen-Dick, R.; May, C.; Haglund, E. Resource conflict, collective action, and resilience: An analytical framework. Int. J. Commons 2013. [CrossRef]

58. Heinmiller, T. Path dependency and collective action in common pool governance. Int. J. Commons 2009. [CrossRef]

59. Haig, B.D. An abductive theory of scientific method. Psychol. Methods 2005. [CrossRef]

60. Bryant, A.; Charmaz, K. The SAGE Handbook of Current Developments in Grounded Theory; Sage: London, UK, 2019. [CrossRef]

61. Transforming Our World: The 2030 Agenda for Sustainable Development. Available online: https://sustainabledevelopment.un. org/content/documents/21252030\%20Agenda\%20for\%20Sustainable\%20Development\%20web.pdf. (accessed on 21 December 2020).

62. Veiga, M.M. Analysis of efficiency of waste reverse logistics for recycling. Waste Manag. Res. 2013. [CrossRef] [PubMed]

63. ANCAT. Anuário da reciclagem 2017-2018; Ancat: São Paulo, Brazil, 2019.

64. Do Nascimento, F.B.; Da Silva, Y.B.R.; da Silva Lima, L.S.; dos Santos, M.D.S.F. Logística reversa dos resíduos de equipamentos eletroeletrônicos de pós-consumo na cidade de Teresina. Sist. Gestão 2018. [CrossRef]

65. Pacheco, G.J.; Pereira de Campos, T.M.; de Mattos Nascimento, D.L. Analysis of the waste management system of electrical and electronic equipment in germany and its influence on the reverse logistics of the municipality of rio de janeiro. Sist. Gestão 2018. [CrossRef]

66. Dyer, J.H.; Singh, H. The relational view: Cooperative strategy and sources of interorganizational competitive advantage. Acad. Manag. Rev. 1998, 23, 660-679. [CrossRef]

67. Dyer, J.H.; Singh, H.; Hesterly, W.S. The relational view revisited: A dynamic perspective on value creation and value capture. Strateg. Manag. J. 2018, 39, 3140-3162. [CrossRef]

68. Chandra, D.R.; van Hillegersberg, J. Governance of inter-organizational systems: A longitudinal case study of Rotterdam's port community system. Int. J. Inf. Syst. Proj. Manag. 2018, 6, 47-68. [CrossRef]

69. Morgan, R.M.; Hunt, S.D. The Commitment-Trust Theory of Relationship Marketing. J. Mark. 1994, 58, 20-38. [CrossRef]

70. Rispens, S.; Jehn, K.A.; Steinel, W. Conflict Management Style Asymmetry in Short-Term Project Groups. Small Group Res. 2020. [CrossRef]

71. Jap, S.D. Pie-expansion efforts: Collaboration processes in buyer-supplier relationships. J Mark Res. 1999. [CrossRef]

72. Rahim, M.A. Toward a theory of managing organizational conflict. Int. J. Confl. Manag. 2002. [CrossRef]

73. Grandori, A. Governance structures, coordination mechanisms and cognitive models. J. Manag. Gov. 1997, 1, 29-47. [CrossRef]

74. Carmona, M. The formal and informal tools of design governance. J. Urban Des. 2017. [CrossRef]

75. Fukuyama, F. Governance: What Do We Know, and How Do We Know It? Annu. Rev. Polit. Sci. 2016. [CrossRef]

76. Guibrunet, L. What is "informal" in informal waste management? Insights from the case of waste collection in the Tepito neighbourhood, Mexico City. Waste Manag. 2019. [CrossRef] [PubMed]

77. Johnson, C.; Dowd, T.J.; Ridgeway, C.L. Legitimacy as a social process. Annu. Rev. Sociol. 2006. [CrossRef]

78. Bodin, Ö. Collaborative environmental governance: Achieving collective action in social-ecological systems. Science 2017. [CrossRef]

79. Tumin, M.M.; Mauss, M.; Cunnison, I.; Evans-Pritchard, E.E. The Gift: Forms and Functions of Exchange in Archaic Societies. Am. Sociol. Rev. 1956. [CrossRef]

80. Rojas-Bermúdez, J.G. Introdução ao Psicodrama; Mestre Jou: São Paulo, Brazil, 1969.

81. Rioch, M.J. The Work of Wilfred Bion on Groups. Psychiatry 1970, 33, 56-66. [CrossRef] [PubMed]

82. Pichon-Rivière, E. Teoria do Vínculo. J. Petrol. 2013. [CrossRef]

83. Powell, W.W. Neither Market nor Hierarchy. Available online: http://www.uvm.edu/pdodds/files/papers/others/1990 / powell1990a.pdf. (accessed on 21 December 2020).

84. Provan, K.G.; Kenis, P. Modes of network governance: Structure, management, and effectiveness. J. Public Adm. Res. Theory 2008. [CrossRef]

85. Sandusky, R.J. Network management. In Understanding Information Retrieval Systems: Management, Types, and Standards; Auerbach: London, UK, 2011. [CrossRef]

86. Mani, S.; Singh, S. Sustainable Municipal Solid Waste Management in India: A Policy Agenda. Procedia Environ. Sci. 2016. [CrossRef]

87. Maes, M.J.A.; Jones, K.E.; Toledano, M.B.; Milligan, B. Mapping synergies and trade-offs between urban ecosystems and the sustainable development goals. Environ. Sci. Policy 2019. [CrossRef]

88. Kiddee, P.; Naidu, R.; Wong, M.H. Electronic waste management approaches: An overview. Waste Manag. 2013, 33, 1237-1250. [CrossRef]

89. Reinhardt, W.; Mletzko, C.; Sloep, P.B.; Drachsler, H. Understanding the Meaning of Awareness in Research Networks. Available online: https:/ / core.ac.uk/reader/55537534 (accessed on 21 December 2020).

90. Shah, C.; Marchionini, G. Awareness in collaborative information seeking. J. Am. Soc. Inf. Sci. Technol. 2010, 61, 1970-1986. [CrossRef] 
91. Diani, M.; McAdam, D. Beyond Structural Analysis: Toward a More Dynamic Understanding of Social Movements. In Social Movements and Networks: Relational Approaches to Collective Action; Oxford Online: Oxford, UK, 2003. [CrossRef]

92. Montanaria, A.; Saberi, A. The spread of innovations in social networks. Proc. Natl. Acad. Sci. USA 2010, 107, $20196-20201$. [CrossRef] [PubMed]

93. Solid Waste Management and Recycling Technology of Japan: Toward a Sustainable Society. Available online: https://www.env. go.jp/en/recycle/smcs/attach/swmrt.pdf (accessed on 21 December 2020). 